\title{
Mentor, Scholar, Academic, and a Massage Therapist: an Interview with Amanda Baskwill, PhD(c), MSc, RMT
}

\author{
Ann Blair Kennedy, LMT, BCTMB, DrPH, \\ Executive Editor, IJTMB \\ University of South Carolina School of Medicine Greenville, Greenville, SC, USA
}

\begin{abstract}
Amanda Baskwill, $\mathrm{PhD}(\mathrm{c}), \mathrm{RMT}$ is influencing the massage therapy profession from seemingly all angles; she is a researcher, massage therapist, educator, innovator, and mentor. Baskwill previously was a full-time faculty member at Humber College in Ontario, Canada, and now holds the position of Associate Dean in the Allied Health School of Health Sciences at the same institution. She has published widely on research centered on the massage therapy profession, as well as the safety and effectiveness of massage therapy as a treatment for various conditions. This interview explores the development, career, and research of the innovative educator and scholar, Amanda Baskwill.
\end{abstract}

With more than 20 published scientific papers, a book chapter, and multiple national and international presentations, this Associate Dean from Humber College in Ontario, Canada is driven to ask the important questions that will help the public and the profession better understand massage therapy and the profession. Amanda Baskwill, $\mathrm{PhD}(\mathrm{c})$, is currently working towards completing her doctorate in Health Research Methodology at McMaster University, and has vast experience in the teaching and development of courses and programs in the field of massage therapy. Her research interests include innovative teaching and learning strategies in health care education, the professional identity of massage therapists, the application of evidence-informed practice, and the safety and effectiveness of massage therapy in the treatment of various conditions. She has been a reviewer and writing mentor for the International Journal of Therapeutic Massage and Bodywork and is the Senior Associate Editor for the Journal of Traditional Chinese Medicine and Acupuncture. In the following interview with Ms. Baskwill, we discuss her vision for the future of massage therapy and massage therapy research.

Please tell us about your massage therapy research and how you feel it has impacted the field of massage therapy.

Much of my research investigates issues of interest to massage therapists themselves. I hope that by shining a light on the profession, we will learn more about who we are - both so we can grow and change, and so we can share with the world what it is we do. The research that I have chosen to undertake is diverse. I have used a variety of methods and have investigated such topics as the experience of male massage therapists, ${ }^{(1)}$ professional identity, ${ }^{(2,3)}$ the use of massage therapy in the treatment of patients with various conditions, ${ }^{(4-6)}$ and challenges and innovations in education. ${ }^{(7-13)}$ Through my own education, I have explored the use of various methodologies, and I endeavor to bring these to the study of the profession. I hope my work has served to inspire others to consider research in their practice, and to consider how they know what they know.

\section{How did you become interested in researching massage therapy?}

I owe my interest in researching massage therapy to Trish Dryden. She was the first professor and massage therapist who made it not only acceptable, but required, to seek to understand how massage therapy worked through research and whether the claims we make are supported. By no means do I wish to suggest that all that does not have research to substantiate it should be abandoned. Rather, I mean to say that precision in language is important when we are unclear as to how or why something seems to have an effect. Trish inspired me to pursue higher education, which was unreservedly supported by my family. Through the process of completing my postgraduate education, I have encountered many researchers who have served as mentors including Kelly Dore, Geoffrey Norman, Lawrence Grierson, Meredith Vanstone, and Susan Jack. It takes a village to raise a researcher.

How do you integrate stakeholders (e.g., practicing massage therapists, massage patients/clients) into your research planning, implementation, and/or dissemination?

From my experience as a registered massage therapist, educator, researcher, and advocate, I have had many ideas for research projects. These grew out of 
my own experiences or from my conversations and observations at various levels. These have been met with enthusiasm by various stakeholders: massage therapists, educators, students, and researchers. First and foremost, I am grateful to all of the practicing massage therapists who continue to show their support by participating in my research. There has always been an overwhelming response from massage therapists when I send an email invitation to participate in a survey or when I post a call for interviewees. I am also fortunate to have massage therapy educators and students with whom to collaborate. I am energized by research, have many more ideas, and am always searching for the next project and coinvestigator.

\section{Where do you see the massage therapy profession and/or massage therapy research in the next five years?}

I hope that massage therapy research continues to look at the mechanisms by which massage therapy works. The more we know about this, the better we understand how best to treat patients. With that said, I hope that, in the next five years, we will study the profession itself; topics such as communication, the therapeutic relationship, and professional identity. Massage therapy is being influenced by the changes in society and in health care. For example, communication skills are more important than ever to ensure patients understand what will happen during treatment and are better able to provide informed consent. It would be helpful to practitioners, educators, and regulators to understand what is currently happening in this area.

\section{Describe a time when one of your projects seems to have failed and what you did to overcome that failure.}

I wouldn't say that research 'fails' per say. Sometimes research does not have the results you would hope for, or it goes off the rails due to any number of factors, such as lack of funding, limited participation, or ethical issues.

Recently, a project I have been working on has been very challenging. First, the original study design was denied funding because the strategies for recruitment were not strong enough. After fortifying them with my coinvestigator, we tried again and were successful. Now that we were funded, we set out to implement our recruitment strategy. It failed! After three months, we had conducted one interview! What did we do? We stuck with it. We talked to anyone we could about our project. We sought out feedback from others about our study. And, with new ideas, we asked the funder for an amendment to our project. While we were not able to recruit as many people as we wanted, we knew that each interview was important, and we took great care to ensure we collected as much information from our participants as possible. There is still much to research on the topic, but with our persistence we have a start to the conversation.

\section{What is it about the massage therapy profession and/or massage therapy research that excites you?}

One of things that excites me about the massage therapy profession and massage therapy research is the potential that exists right now. There are so many opportunities for the direction of practice and research, especially as massage therapists have more and more interactions with other health care practitioners. This means that we are learning new things and thinking about massage therapy in different ways. When the research we conduct is informed by the questions and changes in the profession and practice, we have endless possibilities for our own growth. And, the more we know about massage therapy and how it works, the better that is for our patients. When massage therapists are confident in the care they provide, because they are able to find, understand, analyze and apply the current research, the potential exists to affect the public opinion about massage therapy and massage therapists.

\section{COPYRIGHT}

Published under the CreativeCommons AttributionNonCommercial-NoDerivs 3.0 License.

\section{REFERENCES}

1. Baskwill A, Vanstone M. "Just don't be creepy": A phenomenological study of the experiences of men in massage therapy. J Complement Integr Med. 2017;15(1).

2. Baskwill A. A guiding framework to understand relationships within the profession of massage therapy. J Bodyw Mov Ther. 2016;20(3):542-548.

3. Baskwill AJ, Dore K. Exploring the awareness of research among registered massage therapists in Ontario. J Complement Integr Med. 2016;13(1):41-49.

4. Furlan AD, Giraldo M, Baskwill A, Irvin E, Imamura M. Massage for low-back pain. Cochrane Database Syst Rev. 2015;(9):CD001929.

5. Cabo F, Baskwill A, Aguaristi I, Christophe-Tchakaloff S, Guichard J-P. Shiatsu and acupressure: Two different and distinct techniques. Int J Ther Massage Bodyw. 2018;11(2):4-10.

6. Hill R, Baskwill A. Positive effects of massage therapy on a patient with narcolepsy. Int $J$ Ther Massage Bodyw. 2013;6(2):24-28.

7. .Lisk K, McKee P, Baskwill A, Agur AMR. Student perceptions and effectiveness of an innovative learning tool: Anatomy Glove Learning System. Anat Sci Educ. 2015;8(2):140-148.

8. Baskwill A. Changing the culture of clinical education in massage therapy. Int J Ther Massage Bodyw. 2011;4(4):33-36. 
9. Baskwill A. Facilitating case studies in massage therapy clinical education. Int J Ther Massage Bodyw. 2013;6(2):20-23.

10. Baskwill A, Sumpton B. The use of an informational video to improve patient satisfaction, preparedness, mood, and empowerment. Int J Ther Massage Bodyw. 2015;8(4):12-18.

11. Baskwill AJ, Belli P, Kelleher L. Evaluation of a gait assessment module using 3D motion capture technology. Int J Ther Massage Bodyw. 2017;10(1):3-9.

12. Baskwill A. Developing capability: Transforming massage therapy education through Inquiry-based learning. Int $J$ Ther Massage Bodyw. 2018;11(3):10-14.
13. Dryden T, Baskwill A, Preyde M. Massage therapy for the orthopaedic patient: a review. Orthop Nurs. 2004;23(5):327-332.

Corresponding author: Ann Blair Kennedy, LMT, BCTMB, DrPH, University of South Carolina School of Medicine Greenville, 701 Grove Road, Greenville, SC 29605, USA

E-mail: Kenneda5@greenvillemed.sc.edu 